\title{
Irresistible Ingénues
}

Reading and Writing the Greuze Girl's Body in Diderot's Salon de 1765

\section{Kelsey Roy}

\section{(2) OpenEdition}

\section{Journals}

Electronic version

URL: http://journals.openedition.org/aes/1714

DOI: 10.4000/aes.1714

ISSN: 2258-093X

\section{Publisher}

Laboratoire LISAA

Electronic reference

Kelsey Roy, «Irresistible Ingénues », Arts et Savoirs [Online], 11 | 2019, Online since 15 July 2019, connection on 06 September 2019. URL : http://journals.openedition.org/aes/1714 ; DOI : 10.4000/ aes. 1714

This text was automatically generated on 6 September 2019.

Centre de recherche LISAA (Littératures SAvoirs et Arts) 


\section{Irresistible Ingénues}

Reading and Writing the Greuze Girl's Body in Diderot's Salon de 1765

Kelsey Roy

In mid-eighteenth-century French art and literature, ingénues were a common motif for exploring the body as a mode of expression: they possessed a quality of "artlessness" that was highly valued in the aesthetic and moral theory of this period. In the Rococo aesthetic that had dominated the arts in the early century, the body was a locus of carnivalesque play with appearances: by displaying or mimicking the clothing and mannerisms of different classes and genders, Rococo characters underscored the theatrical aspects of status and identity ${ }^{1}$. In the mid-century, artists and authors began to shift their attention inward, towards an aesthetics of sentiment that celebrated the innermost feelings of human beings: reacting against Rococo-style artifice, which they came to view as corrupt, they favored characters who expressed emotions through heartfelt tears, impulsive gestures, and dramatic poses. Their object was to make striking impressions that produced profound, lasting effects in their readers or beholders. This, in turn, served a broader project of moral reform: by sympathizing with fictional characters, particularly when beholding their suffering bodies, one was thought to awaken to sympathy for others in real life ${ }^{2}$. Ingenuous young women - thoroughly transparent and natural in their manner of expression - made ideal subjects for the sentimental aesthetic ${ }^{3}$

2 In the mid-century, no one explored ingenuousness in sentimental art and literature more prolifically than Denis Diderot. In addition to the famous heroine Suzanne Simonin of his novel La Religieuse (ca. 1760), ingénues featured prominently in his art criticism: he especially admired the work of Jean-Baptiste Greuze, whose paintings of young girls are known today as the "Greuze Girls"4. In most of Diderot's texts, his conception of ingenuousness echoes the main points of the Encyclopédie article "Ingénuité » (1765), which he likely wrote himself ${ }^{5}$.The article initially defines the quality as the absence of self-conscious theatrics and guile. Having little understanding of how to manipulate appearances, or of the social advantages of doing so, ingénues show their genuine thoughts and feelings to everyone: «L'ingénuité est la qualité d'une âme innocente qui se montre telle qu'elle est, parce qu'il n'y a rien en elle qui l'oblige à se cacher. » (8: 744) 
Diderot goes on to link ingenuousness to a natural and involuntary language of the body. Just as the ingenuous "soul" nakedly displays itself in speech, it "paints" itself upon the ingénue's face and form in an intensely pleasing spectacle:

Que le commerce [des personnes ingénues] est agréable! Si elles ont parlé, on sent qu'elles devaient dire ce qu'elles ont dit. Leur âme vient se peindre sur leurs lèvres, dans leurs yeux, et dans leur expression. On leur découvre son cœur avec d'autant plus de liberté, qu'on voit le leur tout entier. Ont-elles fait une faute, elles l'avouent d'une manière qui ferait presque regretter qu'elles ne l'eussent pas commise. ${ }^{6}$

Despite the evident admiration for ingénues that Diderot expresses here, he acknowledges that their innocence is double-edged: in the article's second paragraph, he contrasts ingénuité with its close counterpart naïveté. He contends that naïveté is a form of candor born of strong emotion, whereas ingénuité is a characteristic of an unformed mind:

L'ingénuité a peu pensé, n'est pas assez instruite ; la naïveté oublie pour un moment ce qu'elle a pensé, le sentiment l'emporte. L'ingénuité avoue, révèle, manque au secret, à la prudence ; la naïveté exprime \& peint [...] L'ingénuité semble exclure la réflexion; elle n'est point d'habitude sans un peu de bêtise, la naïveté sans beaucoup de sentiment; on aime l'ingénuité dans l'enfance, parce qu'elle fait espérer de la candeur; on l'excuse dans la jeunesse, dans l'âge mûr on la méprise. $(8: 744)$

4 The intellectual deficiencies that Diderot links to ingenuousness here are twofold: while the first half of this passage simply refers to the ignorance that comes with inexperience, the second half describes a more ingrained «betise» that seems fundamentally incompatible with deep thought. Though the text insists that ingenuousness is pleasing in children, and still "excusable" in adolescents, it gives the overall impression that ingénues are often primitive, vaguely animalistic creatures, given to showing themselves plainly but lacking emotional depth.

5 All of these qualities combine to sketch an ambiguous picture of the attraction that ingénues hold for others. On the one hand, Diderot overtly states that they offer their admirers an exciting chance to engage in a sympathetic rapport: since one can both "see" and "feel" the true essence of their hearts, one can pour out one's heart to them " avec d'autant plus de liberté ». Yet on the other hand, the relationship between ingénues and their interlocutors is inherently unequal: regardless of whether ingénues choose to speak aloud - or are aware of expressing themselves at all - their bodies naturally and transparently articulate their emotional and psychological states. Diderot's remark that " [1]eur âme vient se peindre sur leurs lèvres, dans leurs yeux, et dans leur expression » therefore carries an undertone of voyeurism. Moreover, the ignorance or «bettise » that he associates with ingénues compounds the voyeuristic element of interactions with them: because they are not usually well-versed in the nuances of social behavior, their minds and bodies are vulnerable to any worldly figure who wishes to exploit them. While Diderot generally adopts a benevolent tone in "Ingénuité, » the literary ingénues of his era, from Molière's Agnès (L'École des femmes, 1662) to Laclos's Cécile de Volanges (Les Liaisons dangereuses, 1782), nearly always contend with cunning manipulators. All those who take an interest in ingénues, out of sympathy or selfishness - or both - share some form of desire to uncover or influence another person's innermost character.

In this article, I examine the significance of ingénues in Diderot's aesthetic theory through an analysis of his review of Greuze's most famous Greuze Girl: Une jeune fille qui pleure son oiseau mort (1765), also called Weeping Girl, a sentimental tableau featured in 
Diderot's Salon de 1765. I have chosen to focus on this text for several reasons. Firstly, the Salons present an interesting blend of the textual and the visual: Diderot recounts the experience of beholding images on canvas and strives to recreate the essence of these images in writing. Secondly, his critique of Weeping Girl illustrates the appeal of a suffering ingénue's body with particular nuance: it explores the pleasure one finds in beholding such a body on canvas and in writing, and asks what the role of the reader/ beholder is as its designated audience. Finally, the text offers insight into Diderot's ideas on the aesthetics of painting and writing, and ultimately sheds light on his notion of what makes a superior art critic.

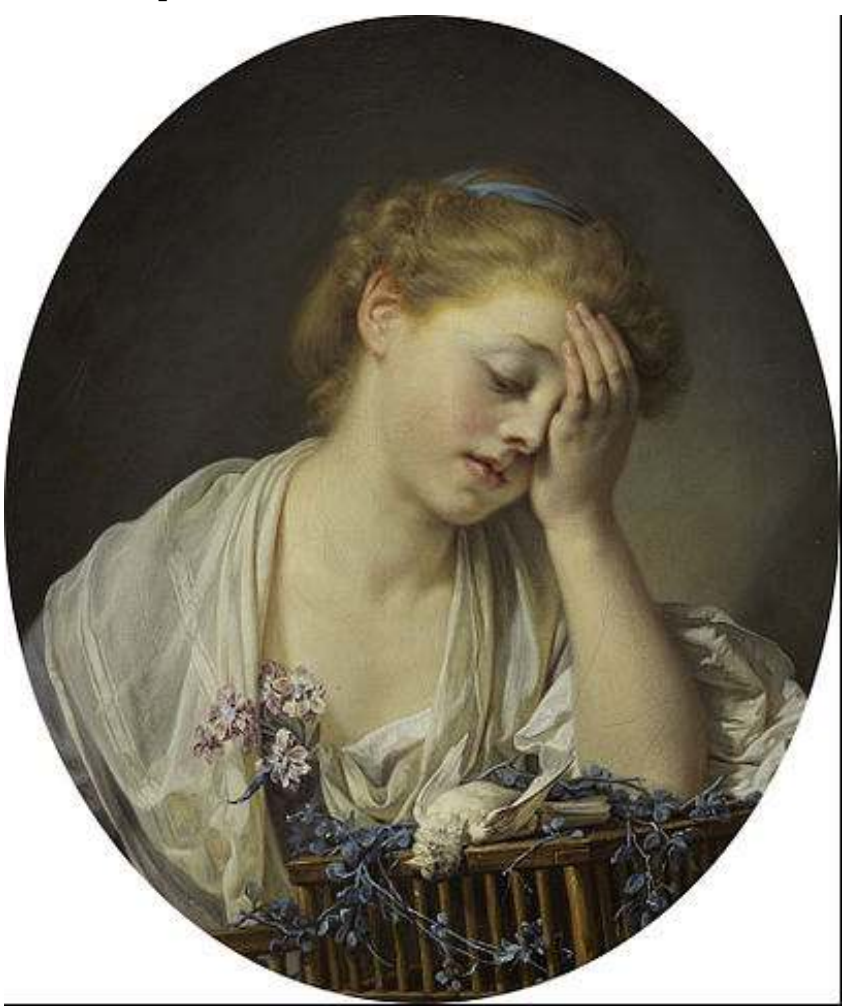

The "jeune fille" and the Aesthetics of Sentiment

Jean-Baptiste Greuze, Une Jeune fille, qui pleure son oiseau mort (1765)

Source: Edinburgh, The National Galleries of Scotland, NG 435. Public Domain, https:// commons . wikimedia.org/w/index. php?curid=21868339

When Diderot wrote his review of Greuze's Weeping Girl for his Salon de 1765, most of his intended readers would likely never see the painting themselves. His Salons originated as a series of letters to his friend Friedrich Melchior, baron von Grimm, who commissioned them for the Correspondance littéraire, philosophique et critique. Grimm circulated his newsletter to only a handful of elite men and women, all of whom lived outside France and relied on it for news of French cultural affairs; the fact that it was hand-copied allowed Grimm to avoid censorship, and to give his readers the sense of sharing in his private correspondence with his contributors ${ }^{7}$. In writing his Salon letters for the Correspondance, Diderot assumed a dual role of art critic and proxy beholder: his reviews were at once a critical evaluation of the artists' exhibits, and an account of his personal feelings on viewing them, so that his readers might imagine the experience for themselves. In his critique of Weeping Girl, he replicates the painting's effect on him with a technique that Bernadette Fort has described as "critical ekphrasis": he reimagines the 
image on canvas as a dramatic scene in which he is taking part, and, in so doing, creates a "reconstruction and interpretation of the painter's representational strategies, goals, and effects"8. Just as Diderot finds himself drawn into Greuze's painting, he contrives to lure Grimm and his other readers into the fantasy he constructs around it.

To those who were able to visit the 1765 Salon in person, Weeping Girl must have made a striking visual impression. It depicts a girl somewhere in early adolescence, seated alone with head in hand and crying over her dead canary. Her bowed head, her hand across her brow, and her downcast eyes partially obscure her face, shifting much of the burden of expression to her body and to the painting's composition. The pale tones in the girl's skin and hair contrast with a dark, empty background, creating a sense of loneliness and vulnerability. White cloth around her shoulders, pink flowers at her breast, and her careless posture lend her an air of naturalness and innocence. The painting's oval frame constricts her world to the space around the bird's cage, further emphasizing her preoccupation with her grief. The overall effect upon the viewer, as Emma Barker argues, is a conflicting sense of closeness to and remoteness from the girl: the fine details of her body make her appear "vividly palpable", as though one could reach out and touch her, yet "the immediacy of her presence is counteracted by [her] emotional withdrawal". The painting's frame therefore serves the additional purpose of underscoring the beholder's voyeurism: its oval shape evokes the act of looking through a spyhole at this girl's private moment of despair. Diderot expresses just such an awareness of distance, and of his own desire to overcome it, in his opening paragraph; he explains that the viewer is tempted to reach into the painting to kiss the girl's hand, but admits that such an action strikes him as transgressive: « On s'approcherait de cette main pour la baiser, si on ne respectait cette enfant et sa douleur. $»^{10}$

Diderot's attraction to the girl's candid display of suffering, and his professed wish to interact with her as though she were real, are rooted in his conception of naïveté and its related concepts, ingénuité and grâce. Of the three qualities, naïveté is the most fundamental to his theories of aesthetics: he perceives it as a key element of "good" art itself, and of the "good" viewer's or reader's emotional response to it. In the former instance, his use of the term echoes its definition in the 1762 Dictionnaire de l'Académie française, which is - after "Ingénuité [...] d'une personne qui n'use point de déguisement » - «cette grâce et cette simplicité naturelle avec laquelle une chose est exprimée, ou représentée selon la vérité et la vraisemblance $»^{11}$. In this sense, naïveté characterizes art that is neither an ornate display of artifice, nor a flatly literal representation of its subject. Rather, it describes art that captures its subject's "true" essence in a way that transcends the artist's means of expression: in the eyes of the viewer or reader, the work becomes the thing by skillfully evoking its deeper nature and bringing it to life. In so doing, it erases the line between reality and fiction altogether, leading the beholder or reader, in Elena Russo's words, "to repress the awareness that he is contemplating a work of art and to feel as if he were responding to the thing itself"12.

Yet as Diderot underscores in his Éloge de Richardson (1762), an artist's or author's skill alone is not enough to produce this effect: it also depends on striking a particular chord within the viewer or reader, which means that not everyone possesses the necessary qualities to fully experience it. The best type of reader (or beholder) of good art, as Diderot describes him in Éloge, is "l'homme tranquille et solitaire, qui a connu la vanité du bruit et des amusements du monde, et qui aime à habiter l'ombre d'une retraite, et à s'attendrir utilement dans le silence ${ }^{13}$. In short, it is an experienced male who possesses 
the right kind of sensibility: the type of mental, passional, and physical disposition that lets him enter the artist's vision of nature "to the fullest degree possible", and to "feel" its truth via the "subtle physiognomy of the passions" 14 . The result is an existential communion with nature that inspires a "childlike naïveté" in the reader or beholder ${ }^{15}$ : it draws him into taking part in the artwork by feeling - and behaving - as though its characters or scenery are real. Diderot recalls losing himself in sympathy for Richardsonian heroes, like Pamela and Clarissa, in precisely this way: «Combien de fois ne me suis-je pas surpris, comme il est arrivé à des enfants qu'on avait menés aux spectacles pour la première fois, criant: Ne le croyez pas, il vous trompe...si vous allez là, vous êtes perdu. » (193; Diderot's italics) Thus, Diderot's idea of naïveté, insofar as it engenders intense emotions that cause the reader/beholder to lose sight of reality - or to become "suspended", to borrow Brian Elkner's term ${ }^{16}$ - closely parallels his theories on the sublime:

Outre la simplicité que [the term naif] exprimait, il faut y joindre l'innocence, la vérité et l'originalité d'une enfance heureuse qui n'a point été contrainte [...] le naïf sera essentiel à toute production des beaux-arts [...] sera tout voisin du sublime [...] se retrouvera dans tout ce qui sera très beau; dans une attitude, dans un mouvement, dans une draperie, dans une expression. C'est la chose, mais la chose pure, sans la moindre altération. L'art n'y est plus. ${ }^{17}$

11 While Diderot appears both awed and amused upon finding himself shouting warnings to fictional characters, his words also recall the sexual violence that fosters the reader's sympathy for Pamela and Clarissa: Richardson highlights their innocence by graphically depicting the brutal assaults they suffer at the hands of libertines. This brings us to the concepts of ingénuité and grâce, and to the crux of Diderot's interest in Greuze's Weeping Girl. In March 1760, five years before the painting's debut, Diderot had written a favorable review of « De la grâce, » a chapter of Claude-Henri Watelet's L'art de peindre (1760) which discusses the trope of the artless girl, or «jeune fille ${ }^{18}$. Watelet defines grâce as the effect of «cet accord des mouvements simples de l'âme avec ceux du corps [que l'on trouve chez les jeunes]", and argues that it is most "seductive" in the female sex: «Le sexe, plus souple dans ses ressorts, plus sensible dans ses affections, dans lequel le désir de plaire est un sentiment en quelque façon indépendant de lui, parce qu'il est nécessaire au système de la Nature; ce sexe [...] offre aussi, lorsqu'il échappe à l'artifice et à l'affectation, les grâces dans l'aspect le plus séduisant $»^{19}$. Moreover, he claims that «les plaintes et les larmes [...] qu'occasionne la perte d'un objet chéri» (112) - such as the Weeping Girl's bird, or, on a far darker note, Clarissa's loss of her virginity to rape - offer a particularly moving show of grâce. His remarks clearly favor a male perspective, and raise the question of exactly what type of attraction such girls hold for men. In theory, the spectacle of a crying girl could simply be taken as the epitome of naif art: a pure display of innocence which appeals to the viewer's moral sensibilities. Yet Watelet's admiring comment on natural feminine sensuality infuses his text with eroticism: it implies that artless femininity is interesting to male beholders because it signals sexual vulnerability as well as emotional vulnerability. With Weeping Girl, and with his other paintings of ingénues, Greuze therefore presents his male viewers with a challenge: in Emma Barker's words, they must "negotiate the tension between the ease of access to the girl's body that [the painting] offers and the ethical prohibition against taking advantage of her youth, innocence, and distress"20. remark that one would reach for the Weeping Girl's hand to kiss it «si on ne respectait 
cette enfant et sa douleur » is significant. It follows an outburst of emotion in his opening lines which attests to Greuze's mastery of the naif aesthetic, and - on its face - portrays Diderot himself as the ideal type of beholder. While he typically begins a Salon review by describing the artwork, or by remarking to Grimm personally about his opinion of it, here he initially seems too overwhelmed to form coherent thoughts. His attention flies back to the girl each time he starts to comment on a different aspect of the painting:

La jolie élégie ! le joli poème ! la belle idylle que Gessner ${ }^{21}$ en ferait ! [...] Elle est de face, sa tête est appuyée sur sa main gauche. L'oiseau mort est posé sur le bord supérieur de la cage, la tête pendante, les ailes trânantes, les pattes en l'air. Comme elle est naturellement placée ! Que sa tête est belle! qu'elle est élégamment coiffée! Que son visage a d'expression! Sa douleur est profonde, elle est à son malheur, elle y est toute entière. Le joli catafalque que cette cage! Que cette guirlande de verdure qui serpente autour a de grâce ! ô la belle main! la belle main ! le beau bras! (Salon, 179-80)

In these lines, Diderot conflates his cultured appreciation of good art with his visceral appreciation of natural feminine beauty. As his language devolves into fragmented, repetitive exclamations about the girl's features, it illustrates the fact that she has struck a resonant chord within him and suggests that he finds his gaze increasingly drawn to her body. On the heels of this, his remark about refraining from kissing her hand reads as a show of self-restraint: though he makes his desire for physical closeness apparent to Grimm and his other readers, he appears prepared to content himself with sympathy for the girl and to "negotiate" the erotic tension by accepting his place outside the painting. In this respect, he seems poised to draw the same conclusion that Grimm himself had drawn about another Greuze Girl in 1761. In his review of Greuze's Un mariage, et l'instant où le père de l'Accordée délivre la dot à son gendre (1761), which appeared in the Correspondance with Diderot's Salon de 1761, Grimm had downplayed the sexual appeal of that painting's titular bride, and had deemed the innocence of her soul to be far more interesting: «[C]'est peu pour elle d'être la plus jolie créature du monde; ses grâces innocentes ne sont pas ce qu'il y a de plus séduisant en elle; mais comment vous peindre tout ce qui se passe dans son âme, au moment de cette révolution si désirable et si redoutée qui va se faire dans toute sa vie ? $»^{22}$ Grimm's insinuation, which Diderot seems to affirm by not reaching for the Weeping Girl's hand, is that the ultimate mark of a "good" Greuzian beholder is that he prefers the ingénue's soul to her body and comes to recognize its superior aesthetic and moral value ${ }^{23}$.

In Diderot's case, however, the purpose of hinting at self-restraint is to make a spectacle of abandoning it altogether: the language of his first paragraph is almost comically exaggerated and is part of a rhetorical strategy that culminates in a fantasy of invading the painting. Immediately after his remark about maintaining distance out of "respect", he resumes his exclaiming and recalls being swept away by his desire for closeness. He tells Grimm of finding himself chanting " Délicieux ! » as though falling under a spell, and claims that his enthusiasm drew him into the painting before he realized what had happened:

Tout enchante en elle jusqu'à son ajustement; ce mouchoir de cou est jeté d'une manière! il est d'une souplesse et d'une légèreté! Quand on aperçoit ce morceau, on dit: Délicieux! Si l'on s'y arrête ou qu'on y revienne, on s'écrie: Délicieux! délicieux! Bientôt on se surprend conversant avec cette enfant et la consolant. Cela est si vrai, que voici ce que je me souviens de lui avoir dit à différentes reprises. ( Salon, 180) 
e lines clearly describe a naif response of the kind that Diderot expressed in the Eloge de Richardson: much as he had called out to Richardson's suffering heroines, he claims to have unwittingly entered the painting to console the girl. Yet in the conversation he imagines with her, his sympathy is disingenuous, because his real purpose is to indulge in a voyeuristic fantasy about her body: he chooses to interpret her dead bird as an allegory of her lost virginity, and "reads" the story of her seduction upon her body's involuntary signs of distress. As he delights in unveiling what he perceives to be her intimate secret, he makes Grimm's presence a part of the text by pausing at times to address him personally. In doing so, he pulls Grimm into sharing in the role of voyeur and adds a layer of complexity to his ekphrastic technique: he not only replicates the painting's effect upon himself, but pushes Grimm - and by proxy, any (male) reader of the Correspondance to scrutinize the true nature of his own interest in suffering ingénues.

In many ways, Diderot's reading of Weeping Girl mirrors the spectacle he describes in his " Ingénuité » article: he takes pleasure in beholding her soul as it paints itself upon her features, and finds her especially alluring because she is "confessing" an indiscretion. As he says in the Encyclopédie, " ont-elles fait une faute, elles l'avouent d'une manière qui ferait presque regretter qu'elles ne l'eussent pas commise ${ }^{24}$. Yet the manner he imagines for the Weeping Girl is prolonged resistance to his gaze: she refuses to speak at all for most of their conversation but is unable to hide any of her thoughts or feelings from him. Her silence, eyes, tears, and the other physical symptoms he detects all betray what he calls the true reason for her grief. Indeed, her refusal to speak only serves to make the pursuit more enjoyable, and to draw Diderot further into the painting:

Çà, petite, ouvrez-moi votre cœur, parlez-moi vrai, est-ce bien la mort de cet oiseau qui vous retire si fortement et si tristement en vous-même?... Vous baissez les yeux, vous ne me répondez pas. Vos pleurs sont prêts à couler. Je ne suis pas père, je ne suis ni indiscret, ni sévère. Eh bien, je le conçois, il vous aimait, il vous le jurait et le jurait depuis si longtemps! Il souffrait tant! le moyen de voir souffrir ce qu'on aime !... Et laissez-moi continuer ; pourquoi me fermer la bouche de votre main ? ( Salon, 180)

Diderot's choice to portray the girl as aware of and resistant to his presence raises the question of what his role is as a naif beholder. His cajoling remark that he is "not a father" is a striking means of claiming a place within the painting: it absolves him from acting as a moral authority and entreats the girl to welcome him as a confidant. It also poses an interesting contrast to Watelet's L'Art de peindre, which names "the father" and "the lover" as the ingénue's archetypical admirers: Watelet claims that compared to « un homme indifférent ", the father is "plus clairvoyant cent fois et plus sensible aux grâces de sa fille ", while the "jeune homme amoureux » expresses the purest love of all (115). His broader argument in delineating these roles, as Emma Barker explains, is that "for a mature male spectator who takes more than a detached interest in the jeune fille, the only available, certainly the only legitimate, subject position was that of a father figure" 25 . In contrast, the role that Diderot creates for himself as a beholder of Weeping Girl lies somewhere between father and lover. When he imagines her impulsively reaching out to press her hand over his mouth, he portrays himself to Grimm and his other readers as a Pygmalion: not merely a father or lover, but a creator who has brought a coveted artistic vision to life in his own mind and in writing. Thus, he claims to be at once a spectator seduced into seeing the girl on canvas as real, and the author of a fantasy in which he "seduces" her into initiating physical contact with him. 
Diderot's self-appointed role as both creator and seducer extends to the way in which he narrates the girl's loss of virginity. The events of the story he writes are extremely clichéd in themselves: her admirer came to her when her mother was out and appealed to her pity with tearful pleas of love. As Diderot pretends to guess at the intimate details while the girl listens in silence, he amuses himself by approaching the crucial moment without overtly stating it:

Ce matin-là, par malheur votre mère était absente ; il vint, vous étiez seule ; il était si beau, si passionné, si tendre, si charmant, il avait tant d'amour dans les yeux, tant de vérité dans les expressions ! il disait de ces mots qui vont si droit à l'âme ! et en les disant il était à vos genoux; cela se conçoit encore. Il tenait une de vos mains, de temps en temps vous y sentiez la chaleur de quelques larmes qui tombaient de ses yeux et qui coulaient le long de vos bras. Votre mère ne revenait toujours point; ce n'est pas votre faute, c'est la faute de votre mère... Mais voilà-t-il pas que vous pleurez! (Salon, 180-181)

As the banality of Diderot's words suggests, the facts of the girl's seduction are not truly important in themselves. What is essential is the pleasure that he finds in drawing them out of her and noting them with his skillful eye: much in the way he imagines her seducer overcame her shy reluctance, Diderot's cajoling makes a game of uncovering her secret despite her resistance. The erotic overtones of his language become even more pronounced as he continues: he punctuates his text with teasing questions like "Continuerai-je?" and «Vous le voulez?», which mimic things one might expect her lover to have said. He describes her lover's departure with a facetious double entendre, namely, as repeatedly "going out and coming back in"; this could also be a reference to his own experience with the painting at the Salon, as he claims to have spoken to the girl "à différentes reprises ": "Qu'il eut de peine à s'arracher d'auprès de vous !... Comme vous me regardez! Je sais tout cela. Combien il se leva et se rassit de fois! combien il vous dit, redit adieu sans s'en aller! combien de fois il sortit et rentra!» (181) Despite the strong element of humor in all of these passages, they confirm Diderot's usurpation of the seducer's place within the painting. His flattering assurance to the girl of her lover's fidelity, which finally earns him a spoken reply, is a cliché worthy of a libertine: « Quand on a été assez heureux pour rencontrer une enfant charmante comme vous, pour s'y attacher, pour lui plaire, c'est pour toute la vie... Et mon oiseau ?... Vous souriez... » (181)

Since the girl Diderot imagines is blind to the playful and mocking aspects of his language, his use of libertine clichés, literary tropes, and tongue-in-cheek wordplay is ultimately for Grimm's benefit. Throughout his text, Diderot seems to enjoy making a spectacle of the girl for Grimm as much as he enjoys creating this fantasy for himself. Even as he experiments with the role of a naif beholder and exclaims about the girl's absorbing effect on him, he teases Grimm about the pleasure that Grimm himself could have had, had he only been present to see her: "Quand on a été assez heureux pour rencontrer une enfant charmante comme vous, pour s'y attacher, pour lui plaire, c'est pour toute la vie... Et mon oiseau ?... Vous souriez... (Ah mon ami, qu'elle était belle! si vous l'aviez vue sourire et pleurer!) Je continuai.» (181) His choice to describe the sensual details of the girl's scene with her lover, only to break off his discourse before arriving at the climactic moment, also reminds the absent Grimm of the distance that separates him from the painting while Diderot enjoys his own fantasy "within" it.

Diderot's rhetorical questions, like "Vous le voulez?» and «Continuerai-je?», could thus be read as asides to Grimm as well as queries to the girl: they seem to ask him how much more he would like to read about the girl's seduction, and to push him to recognize 
the fact that he wants Diderot to reveal it all. Much as Diderot began his experience with the painting as a voyeur, gazing in upon the girl from outside the frame, it is now Grimm who gazes in upon her through the lens of Diderot's text. It is also up to Grimm to confront this distance by using his imagination to fill in the text's gaps, just as Diderot has done for himself with the painting ${ }^{26}$. Yet doing so requires him - and by extension, any male subscriber to the Correspondance - to accept what Diderot believes to be the "truth" of Weeping Girl: not only that it is meant to be an allegory of lost virginity, but that it interests men primarily because of the sexual subtext that Diderot perceives in it. In other words, it is interesting to men as art that stimulates their imagination and invites them to project their banal male desires upon a vulnerable, ingenuous female body. In challenging Grimm with this truth, Diderot acts out the ultimate challenge that Greuze's paintings of ingénues pose to the beholder: as Janie Vanpée argues, the beholder "can either welcome the call and pleasure to participate in the making of the fantasy, or [...] can feel unease at [his] complicity with fantasies that usually remain hidden and unarticulated"27. Should Grimm choose to accept this call, and to admit his own ordinary desires, creating a naif fantasy ought to be easy for him as a philosophe and man of the world. Should he reject it, he is left to contemplate his own discomfort. Either way, Diderot's text achieves the same objective that Vanpée pinpoints at the heart of Greuze's work: it "redirects the viewer's gaze inward" and forces him to reflect upon his personal response to this kind of $\operatorname{art}^{28}$.

There is one final point to be made about Diderot's use of humor to achieve this effect, and the broader role that humor plays in his conception of the "good" reader/beholder. He concludes his reading of Weeping Girl by upholding it as evidence of his superiority as an art critic, and scoffs that most of the other Salon critics missed the painting's subtext: «beaucoup de personnes ne l'ont pas entendu [...]. Ne pensez-vous pas qu'il y aurait autant de bêtise à attribuer les pleurs de la jeune fille de ce Salon à la perte d'un oiseau, que la mélancolie de la jeune fille du Salon précédent à son miroir cassé ? Cette enfant pleure autre chose, vous dis-je. $»^{29}(182-3)$ Yet he makes this claim only after shattering the fantasy he had enthusiastically constructed, and mocking himself for having felt so absorbed in it. As he turns his gaze inward to contemplate his own willingness to be carried away, he invites Grimm to share a laugh at it, while still admitting to the attraction that the girl holds for him: « [M]on ami, ne riez-vous pas, vous d'entendre un grave personnage s'amuser à consoler une enfant en peinture de la perte de son oiseau, de la perte de tout ce qu'il vous plaira? Mais aussi voyez donc qu'elle est belle! qu'elle est intéressante ! Je n'aime point à affliger, malgré cela, il ne me déplairait pas trop d'être la cause de sa peine. » (182) The point of this self-mockery is not to trivialize the experience he has just had; rather, it is to establish the importance of restoring his critical perspective afterward. To laugh at himself for losing control is a means of regaining control. In other words, it is the necessary final step which allows him to transition back from absorbed beholder into discerning observer.

In Diderot's eyes, therefore, the good reader/beholder and ultimately, the superior art critic, is not merely someone who can lose himself in naif art, or whose sympathy for suffering innocents leaves him feeling morally edified. He is also someone who can critically evaluate his own susceptibility to the fictional world; who can enter a painting and come out again; who can recognize all the facets of his interest in the image on canvas, including the dark, the amusing, and the banal. Above all, he is someone who can create a narrative that pulls his readers in and challenges them to become "suspended" in 
the artwork's truth, even as he laughs at himself for having had the same experience as a beholder. Diderot's chosen proof of his right to count himself such a person is the Salons themselves: that work, ultimately, forms the experimental body of texts in which he pushes the limits of language and art criticism.

\section{NOTES}

1. See Sarah R. Cohen, "Body as 'Character' in Early Eighteenth-Century French Art and Performance", The Art Bulletin, 78:3, September 1996, p. 454-466.

2. See for example David Marshall, The Surprising Effects of Sympathy: Marivaux, Diderot, Rousseau, and Mary Shelley, Chicago and London, University of Chicago Press, 1988.

3. On ingénues as an antithesis of the Rococo, and their place in the Enlightenment project of reforming the arts, see Elena Russo, Styles of Enlightenment: Taste, Politics, and Authorship in Eighteenth-Century France, Baltimore, The Johns Hopkins University Press, 2007, p. 105-112.

4. Emma Barker traces the first documented use of the term to John Rivers' Greuze and His Models, London, Hutchinson \& Co., 1912. See Barker, "Reading the Greuze Girl: The Daughter's Seduction", Representations 117, 2012, p. 87.

5. «Ingénuité ", Encyclopédie, ou Dictionnaire raisonné des sciences, des arts, et des métiers, ed. Denis Diderot \& Jean Le Rond d'Alembert, Paris, Chez Briasson [et al], 1751-1772, 17 vols.; vol. 8 (1765), p. 744. Citations are taken from the University of Chicago: ARTFL Encyclopédie Project, Autumn 2017 Edition, ed. Robert Morrissey and Glenn Roe, http://encyclopedie.uchicago.edu/. ARTFL marks this article as an "uncertain attribution" to Diderot because it was unsigned. Given its stylistic similarities to articles he did sign, like "Innocence", and its close parallels with ingénues who appear in Diderot's work in this period, I have chosen to refer to him definitively as its author.

6. While Diderot does not explicitly constrain his remarks to female ingénues in this article, he only cites female examples of ingenuous characters: Agnès of Molière's L'École des femmes (1662) and the tragic heroine of Racine's Iphigénie (1674). Furthermore, as Élise Pavy-Guilbert explains, "Dans l'imaginaire du XVIII ${ }^{\mathrm{e}}$ siècle comme dans celui [de Diderot], c'est la femme, plus sujette aux passions et plus proche de l'état de nature, qui permet de penser ce rapport immédiat [entre le corps et l'âme]. » (L'Image et la langue : Diderot à l'épreuve du langage dans les Salons, Paris, Classiques Garnier, 2014, p. 302)

7. See Stéphane Lojkine, L'Eil révolté : les Salons de Diderot, Paris, Éditions Jacqueline Chambon / Arles, Actes Sud, 2007, p. 60-68, p. 89; and Else Marie Bukdahl, Diderot, critique d'art I: Théorie et pratique dans les « Salons » de Diderot, Copenhagen, Rosenkilde et Bagger, 1980.

8. Bernadette Fort, "Ekphrasis as Art Criticism: Diderot and Fragonard's 'Coresus and Callirhoe”, in "Icons, Texts, Iconotexts: Essays on Ekphrasis and Intermediality", European Cultures: Studies in Literature and the Arts, ed. Peter Wagner, Berlin and New York, Walter de Gruyter, 1996, p. 62. On the emergence of art criticism as a genre in the eighteenth century, and Diderot's role in its development, see Richard Wrigley, The Origins of French Art Criticism: from the Ancient Régime to the Restoration, Oxford, Clarendon Press, 1993, p. 232-267.

9. Barker, art. cit., p. 89, p. 94.

10. Diderot, Salon de 1765, ed. Else Marie Bukdahl, Annette Lorenceau, et Gita May, in CEuvres complètes, vol. XIV, Paris, Hermann, 1984, p. 180. 
11. The terms naïveté and ingénuité were sometimes used synonymously in the eighteenth century, as is the case in the 1762 Dictionnaire. In the second half of the century, some authors like Diderot and Choderlos de Laclos lent "naïf » a more positive connotation than « ingénu ", but the definition of «naïveté » remained unchanged in the 1798 edition of the Dictionnaire de l'Académie.

12. Russo, op. cit., p. 93. On Diderot's ideas of "uncovering" nature through the creation and contemplation of art, see also Jacques Chouillet, La Formation des idées esthétiques de Diderot (1745-1763), Paris, Librairie Armand Colin, 1973, p. 324-345.

13. Denis Diderot, Éloge de Richardson in CEuvres complètes, ed. Jean Varloot et al., op. cit., 1980, vol. XIII, p. 197.

14. Anne C. Vila, Enlightenment and Pathology: Sensibility in the Literature and Medicine of EighteenthCentury France, Baltimore, The Johns Hopkins University Press, 1998, p. 156, 158.

15. Ibid., p. 155.

16. Elkner argues that Diderot's definition of "the sublime" varies, but that the "idea of suspension" underlies all his uses of the term: "In the sublime response to art, the imagination is carried beyond the normal operations of the understanding and the memory, which are suspended in favour of the freedom of the subjective reaction. The accessory ideas which flood into the mind as a result of this subjective freedom have the further effect of suspending the spectator in time and space, giving him a profound sense of his own littleness without exposing him to complete despair" ("Diderot and the Sublime: Artist as Hero", in Studies in the Eighteenth Century II, Papers Presented at the Second David Nichol Smith Memorial Seminar (Canberra 1970), ed. R.F. Brissenden, Canberra, Australian National University Press, 1973, p. 160).

17. Diderot, Pensées détachées sur la peinture, in Euvres esthétiques, ed. Paul Vernière, Paris, Éditions Garnier Frères, 1968, p. 824.

18. Emma Barker notes that this was the only section he praised; his review of the text for the Correspondance was "otherwise damning" (art. cit., p. 98).

19. Claude-Henri Watelet, L'Art de peindre, poème avec des réflexions sur les différentes parties de la peinture, éd. Amsterdam [1761], Geneva, Slatkine Reprints, 1969, p. 112, p. 114.

20. Barker, art. cit., p. 97.

21. Salomon Gessner (1730-1788) was a Swiss author of pastoral poetry, best known for his idealized depictions of familial love, piety, and virtue.

22. Friedrich Melchior, baron von Grimm, Correspondance littéraire, t. VIII [1761], ed. Ulla Kölving, Else Marie Bukdahl, Mélinda Caron, Ferney-Voltaire, Centre international d'étude du XVIII ${ }^{\mathrm{e}}$ siècle, 2013, p. 374. Diderot's critique of Weeping Girl echoes Grimm's remarks on L'Accordée de village in other ways: Grimm bestowed most of his praise for L'Accordée upon the bride, and described the painting as « le plus agréable et le plus intéressant de tout le Salon [de 1761]» (p. 369). Four years later, Diderot lavished the same praise on Weeping Girl, which he described to Grimm as "[le tableau] le plus agréable et peut-être le plus intéressant du Salon » (Salon, p. 179).

23. On this point, and on the interplay between eroticism and moralism in L'Accordée de village, see Emma Barker, Greuze and the Painting of Sentiment, Cambridge, Cambridge University Press, 2005, p. 53.

24. «Ingénuité », p. 744.

25. Art. cit., p. 98.

26. On this point, the text echoes Diderot's critical writings on sketches, in which he also explores the role of the viewer's imagination in completing an unfinished image. See Caroline Jacot Grapa, Diderot et l'esquisse : La danse de l'esprit, L'Esprit créateur, 56:4, 2016, p. 22-34.

27. Janie Vanpée, “Jean-Baptiste Greuze: the Drama of Looking”, L'Esprit créateur, 28: 4, 1988, p. 66.

28. Ibid. 
29. Diderot is categorizing Weeping Girl with Greuze's Le Miroir cassé of 1763. Emma Barker argues that unlike Weeping Girl, Le Miroir cassé is an unequivocal allegory of lost virginity because "the young woman's disheveled state, the disorder of her surroundings, and such erotically charged details as a pearl necklace and an open letter all reinforce the sexual significance of the subject" (art. cit., p. 92).

\section{ABSTRACTS}

The ingenuous girl was an integral motif in Diderot's musings on the body as an aesthetic object. This essay proposes a reading of his review of "Weeping Girl", a painting by Jean-Baptiste Greuze that featured in Diderot's Salon de 1765. In this text, Diderot narrates a fantasy of entering Greuze's painting to decipher the girl's physical signs of distress. In doing so, he explores the allure of expressive female bodies and the power of his own imagination, and ultimately demonstrates his notion of what makes a superior art critic.

Le motif de l'ingénue fait partie intégrante des réflexions de Diderot sur le corps comme objet esthétique. Cet article analyse le compte rendu que fait Diderot du tableau de Jean-Baptiste Greuze Une jeune fille qui pleure son oiseau mort dans son Salon de 1765. Dans ce texte, Diderot imagine qu'il entre dans le tableau afin de déchiffrer les signes de détresse physiques de la jeune fille. Ce faisant, il explore le pouvoir de séduction des corps féminins expressifs ainsi que le pouvoir de sa propre imagination, pour finalement mettre en avant ce qui, selon lui, constitue un critique d'art supérieur.

\section{INDEX}

Mots-clés: corps féminin, Diderot (Denis), Greuze, ingénue, Salons, sentimentalisme Keywords: female body, Diderot (Denis), Greuze, ingénue, Salons, sentimentalism

\section{AUTHOR}

\section{KELSEY ROY}

University of Wisconsin-Madison 